\title{
Corporate Governance and Efficiency of Rural and Community Banks (RCBs) in Ghana
}

\author{
Eric Fosu Oteng-Abayie**, Anthony Affram^, \\ Henry Kofi Mensah" \\ ^Department of Economics, Kwame Nkrumah University of Science and Technology, Ghana \\ -School of Business, Kwame Nkrumah University of Science and Technology, Ghana
}

Submitted: April 16, $2018 \bullet$ Accepted: September 28, 2018

\begin{abstract}
Corporate governance crises that occur in the banking sector normally cripple economies and bring many hardships to individuals, corporate entities, communities, and the nation at large. In this study, we sought to examine the level of technical efficiency and productivity growth of rural and community banks (RCBs) and the impact of corporate governance indicators on the RCBs' efficiency performance in Ghana. A sample of 70 out of 140 RCBs was selected based on the ARB Apex Bank's performance ratings and data availability. Data envelopment analysis (DEA) was used to determine the technical efficiency scores of the selected RCBs. In the second stage of the analysis, these computed efficiency scores were regressed on the corporate governance variables to assess the effects of the latter. The findings from the DEA approach show that $11 \%$ to $20 \%$ of the sampled RCBs in Ghana operate close to the efficiency frontier, whereas the majority-about $65 \%$ to $81 \%$-underperformed within the study period of 2007 to 2013. The study further established that the number of board members, frequency of board meetings, and corporate social responsibility have significant influence on RCB efficiency.
\end{abstract}

JEL classification: C14, D24, G21, G32, G34

Keywords: data envelopment analysis, technical efficiency, corporate governance, rural banks, Ghana

${ }^{*}$ Corresponding Author. Email: efoteng-abayie.socs@knust.edu.gh 


\section{Introduction}

Good corporate governance is increasingly acknowledged as a significant driver of long-term investment and has become a crucial subject in financial circles. Such governance has become necessary for any organization serious about optimizing its performance. The literature on this subject also contains evidence of a positive correlation between the level of corporate governance and bank crises. Bank crises are argued to be a long-term result of a series of bad corporate decisions. Decisions critical for bank survival, including incentives, performance targets, provision of internal controls, and strategy, are all taken by the board of governors. As a result, corporate governance is seen as a vital key to understanding institutional efficiency and productivity. On the international front, cases such as Enron, WorldCom, Pacific Gas and Electricity Company, and Barings Bank are commonly cited. In Ghana, Atobease Rural Bank, DKB Finance, Merchant Bank, and Noble Dream Microfinance are commonly cited examples of the negative repercussions of weak corporate structures. In July 2018, the Bank of Ghana also cited corporate governance practices as the underlying factor for the collapse of seven commercial banks in Ghana between 2016 and 2018.

Adnan et al. (2011) indicate the need for strong corporate structures in the banking sector. A number of studies have thus attempted to assess the effect of corporate governance on bank performance. Recent additions include Fidanoski et al. (2014), Ameer et al. (2010), Tahir (2015), Poudel (2013), and Rao and Desta (2016). A common observation made from these extant studies is that banks rely too much on accounting indices to evaluate corporate performance. However, accounting indices are always single-factor input or output measures of performance and may be considered as "just scratching the surface" It is particularly useful to measure performance from multiple activities because financial institutions combine multiple inputs to produce different financial outputs.

Meanwhile, since the inception of rural banking in Ghana, concerns about limited capacity and liquidation threats, amidst fierce competition from the commercial banks, remain rife. Several rural and community banks (RCBs) have been closed down by the Bank of Ghana due to financial difficulties. In 2012 alone, 15 RCBs were classified as distressed, and 19 others were identified as mediocre banks. A 2012 Bank of Ghana report indicates that a total of 23 distressed RCBs have been shut down by the central bank since 2007 (OtengAbayie, 2017). These developments suggest a strong link between corporate governance and RCB performance. Despite the recent interest in corporate governance, studies of its effects on rural banking performance remain few. To the best of our knowledge, the deficit is even larger when the Ghanaian context is considered. Empirical research on the subject is largely non-existent, with the exception of Bokpin (2013) for commercial banks and other studies that focused only on rural bank efficiency and productivity (see Adusei, 2016; Oteng-Abayie, 2017). 
The purpose of this paper is to examine the effects of several attributes of corporate governance, in particular, size of the board of directors and audit committee, frequency of board meetings, and corporate social responsibility, on the efficiency of RCBs in Ghana. We first estimate the technical efficiency levels and then examine the effects of corporate governance indicators on the efficiency performance of RCBs in Ghana. We employ the data envelopment analysis (DEA) approach to measure bank performance. The significance of using the DEA approach is that it allows for the assessment of bank performance using an array of output and input variables, unlike the one index performance measure that mostly characterizes the extant bank governance literature. Therefore, we can capture the real effect of corporate governance on the efficiency performance of RCBs. This study focuses on a unique dataset retrieved from the financial accounts of RCBs in Ghana from 2007-2013. Our findings from the DEA approach show that $11 \%$ to $20 \%$ of the sampled RCBs operate close to frontier efficiency, whereas the majority-about $65 \%$ to $81 \%$-underperformed within the study period. The study established that the number of board members, frequency of board meetings, and the level of corporate social responsibility have significant influence on RCB efficiency.

The rest of this paper is organized as follows. Section 1 presents a brief literature review and the methodology is presented in the second section. Section 3 describes the data. Section 4 captures the data analysis and presentation of empirical results and the final section concludes and presents the practical implications of the study results.

\section{Review of Related Literature}

The evolution of thinking about corporation governance is traced to Berle and Means (1932) regarding the consequences of separating corporate control and ownership and then to Jensen and Meckling (1976) regarding agency theory. Corporate governance has been expressed as the processes and procedures through which firms are guided and controlled for effective decision-making (European Central Bank, 2004). Black et al. (2006) concluded that the way corporate governance is measured matters. Corporate governance in banks has been measured in diverse ways in the existing literature. For instance, whereas some studies use single indicators (Tanna et al., 2011; Laeven and Levine, 2009), others find it more convenient to use multiple indicators (such as board size, experience and independence of board members,

and gender diversity, among others) to increase robustness of the measurement (Hartarska and Mersland, 2012; Romano et al., 2012; Huang, 2010). In this study, we use multiple indicators of corporate governance. 


\subsection{Corporate Governance and Efficiency of Banks}

A plethora of studies exist that explore the effect of corporate governance on corporate performance (see Achim, 2016; Soba et al., 2016; Andries et al., 2018, for a summary of the empirical literature). The general consensus is that the effect of corporate governance on firm performance is mixed (Beisland et al., 2014). The effects are highly dependent on contextual factors as well as the measures of corporate governance and firm performance.

Gleaning from Andrieş et al. (2018) and Soba et al. (2016), studies focusing on the link between corporate governance and bank performance are growing in the literature. Earlier studies measured performance using traditional accounting-based ratios (e.g., pre-tax operating income, return on assets, market-to-book value, Tobin's $Q$, and the non-performing loans ratio) that are not multidimensional to studies that use robust frontier efficiency methods. Accounting-based indicators have, however, received large amounts of criticism. Therefore, with the availability of more robust mathematical programming and econometrics techniques, most recent studies have used frontier efficiency approaches to measure bank performance (Tanna et al., 2011). In Table 1, we present a summary of the empirical literature on the effects of corporate governance on bank performance. However, as shown in the table, studies that applied frontier efficiency methods are limited and their findings do not converge.

Performance measurement relying on frontier efficiency techniques such as the DEA is strongly recommended in the bank performance literature (Berger and Humphrey, 1997). The efficiency measures have several advantages over traditional indicators of performance. Efficient frontier approaches provide an overall objective numerical score and ranking, an efficiency proxy that complies with an economic optimization mechanism (Tanna et al., 2011). Also, the frontier efficiency approach simultaneously takes into account more than one input and one output of a firm, in contrast to accounting-based performance ratios (Thanassoulis et al., 1996).

Based on the reviewed empirical literature, we contribute to the existing studies by employing the frontier efficiency DEA technique to aid in determining the effect of corporate governance on bank performance. This will be the first study of its kind in the context of RCBs in Ghana.

\section{Methodology}

\subsection{Efficiency Model}

In order to investigate the empirical effect of corporate governance on the performance of RCBs, this study uses efficiency scores computed using the DEA model. The first part of the data analysis involves calculating the efficiency score of the $i$ th RCB. DEA is a commonly 
applied linear programming technique used for constructing a piece-wise frontier surface that can be used to evaluate the relative efficiency of identical decision-making units (DMUs) by capturing how each of them deviates from the idealized production output of the virtual DMU. DEA may adopt either Constant Returns to Scale (CRS), as first used by Charnes et al. (1978), or Variable Returns to Scale (VRS), later used by Banker et al. (1984). DEA, under the assumption of CRS or VRS, can be estimated by applying either the input-oriented or output-oriented approach.

In the input-oriented approach, efficiency is calculated as the proportional reduction in input usage given an observed level of output, whereas under the output orientation, efficiency is calculated as the proportional increase in output level given the observed input usage. For a detailed exposition of the DEA approach, see Murillo-Zamorano (2004).

In this paper, we employ the output-oriented DEA approach, motivated by the general observation that the RCBs have been put under a different categorization based on industrial ratings, which are performance-based. Thus, assuming that all the RCBs in the sample operate at an optimal scale would be incorrect. Moreover, we execute an output-oriented DEA approach based on the simple reason that the objective of RCBs in Ghana through the years has been to mobilize rural savings and capital. The RCBs are doing this by competing with peers, commercial banks, and other financial institutions in the financial market. Recent developments have resulted in most RCBs establishing new branches, collection points, and a variety of innovative products and programmes in a bid to compete in the market. Thus, we anticipate that increasing financial output is of primary importance to RCBs in Ghana.

The DEA efficiency score for the $i$ th RCB is calculated by solving the following linear programming problem:

$$
\begin{aligned}
\operatorname{Max} \theta & \text { subject to } \\
-\theta q_{i}+\mathbf{Q} \lambda & \geq \mathbf{0}, \\
x_{i}-\mathbf{X} \lambda & \geq \mathbf{0}, \\
\mathbf{1}^{\prime} \lambda & =1, \\
\lambda & \geq \mathbf{0}
\end{aligned}
$$

where $y_{i}$ is a vector of outputs, $x_{i}$ is a vector of inputs, $\mathbf{1}$ is an $N \times 1$ vector of ones, and $\lambda$ is a $N \times 1$ vector of constants. Computed $\theta$ lies between 0 and 1 . This means that when the computed efficiency score is equal to 1 , then the DMU is said to be efficient and is otherwise considered inefficient. The symbol $\lambda$ is the weight assigned to a DMU. Hence, $\theta$ and $\lambda$ are the so called dual variables. 


\subsection{Determinants of Efficiency}

Subsequently, computed efficiency scores are used as dependent variables and regressed on the corporate governance variables. This study adopts the pooled OLS regression model, which follows the normal OLS estimator assumptions. The model is expressed as:

$$
Z_{i, t}=\alpha+h_{i, t} \beta+e_{i, t}, \quad i=1,2,3 \ldots N, \quad t=1,2 \ldots T
$$

where $Z_{i, t}$ is the efficiency score of each RCB at time $t, h_{i, t}$ is the vector of corporate governance indices, $\beta$ is a vector of parameters, $\alpha$ is the constant term, and $e_{i, t}$ is the random error term. The empirical estimable equation is expressed as:

$$
\theta_{i, t}=\beta_{0}+\beta_{1} N B M_{i, t}+\beta_{2} F B M_{i, t}+\beta_{3} A C S_{i, t}+\beta_{4} F A C M_{i, t}+\beta_{5} C S R_{i, t}+e_{i, t}
$$

\section{Data}

The data for this study were extracted from audited annual reports of the RCBs for the period 2007-2013, kept by the ARB Apex Bank. Based on the available data, 70 out of 140 RCBs were used for the analysis. The ARB Apex Bank serves as a central bank and regulator for rural and community banks in Ghana. The ARB Apex Bank assesses the performance of RCBs in four major rating areas as strong, satisfactory, fair, marginal, or distressed based on their capital, assets (including asset quality and asset utilization), savings/profitability, and liquidity. The sample used comprises 10 strong, 35 satisfactory, 15 fair, and 10 marginal RCBs.

\subsection{Input and Output Variable Specification}

This study adopts the intermediation approach because RCBs in Ghana take savings from depositors and lend them out to prospective borrowers (Paxton, 2003). Deposits and operating expenses (including interest expenses) are treated as inputs, whereas interest income and loans are treated as outputs (see Soba et al., 2016). All the variables used in the model are measured in Ghanaian Cedis. The variable descriptions and expected signs are presented in Table 2 and the descriptive statistics of the input and output variables are in Table 3. 


\section{Empirical Results}

\subsection{Technical Efficiency Estimates}

Efficiency scores of all the RCBs were determined through DEA analysis. The efficiency indices were measured based on the VRS and output orientation assumptions. Table 4 gives a frequency distribution of technical efficiency scores based on the VRS-DEA output-oriented approach. The technical efficiency scores do not differ much from the VRS input-oriented approach or from the scores generated with the CRS approach (see Figures 1, 2, 3 and 4). A visualization of the trends in overall average efficiency shows that the RCBs experienced a fall in technical efficiency from 2007 to 2011 and picked up from 2011 to 2013. The period of the decline may be attributed to the global financial crises when banks experienced financial difficulties and credit crunches. All the RCBs that obtained a computed efficiency score equal to unity are regarded as fully efficient, whereas all those with scores less than 1 are referred to as inefficient. From Table 4, we observed that the annual technical efficiencies for the individual RCBs ranged from a minimum of $11.20 \%$ to a maximum of $100 \%$. Average annual technical efficiency scores for all 70 RCBs varied from $54.28 \%$ to $69.36 \%$, suggesting that the sampled RCBs were generally technically inefficient during the sampled period. This is also reflected in the number of technically efficient RCBs. A closer look at the annual technical efficiency scores revealed that most of the sampled RCBs received efficiency scores of $51 \%$ to $90 \%$. Figures 1 and 2 show the average technical efficiency during the study period for each RCB. Only three of the 70 RCBs sampled achieved full technical efficiency consistently during the study period. The CRS efficiency score, which is more flexible, returns about 10 fully efficient RCBs. The least efficient bank (RCB59) achieved an efficiency score of $18.3 \%$.

\subsection{Effect of Corporate Governance on Technical Efficiency}

Table 5 reports the effects of the corporate governance variables on technical efficiency (TE) of the RCBs based on equation 3. Based on the model statistics, which show a minimal Root MSE (17.793), we focus on the constant returns TE (CRS) model for interpretations. The results show that the number of board members (NBM) has a positive and significant effect on efficiency, suggesting that a large board size is more technically efficient than a smaller one. Other studies that find a positive relationship between board size and bank efficiency include Soba et al. (2016), Bokpin (2013), Poudel (2013), and Tanna et al. (2011). Anderson and Campbell (2004) also found evidence to suggest that boards of larger size monitor managers to track a reduced cost of debt. Creditors are of the view that those firms have good and efficient monitoring systems to ensure strong accounting procedures for firm performance. However, this finding is inconsistent with Jensen's agency theory, which 
suggests that smaller board size is beneficial for driving organizational outcomes (Jensen, 1993). Damme et al. (2016) report findings for microfinance institutions in support of the agency theory.

The frequency of board meetings (FBM) is significant at 10\%, and reveals a positive influence on RCB efficiency. This is consistent with the view that boards which meet frequently may overcome the risk of information asymmetry and can address issues on time before they get out of control. Tai (2015) stated that, like board size, more frequent board meetings might lead to better firm effectiveness. Likewise, Ntim and Osei (2011) stated that there is an important and positive alliance among the performance of corporations and the series of board meetings. Moreover, experts have argued that increasing the frequency of board meetings will assist directors to keep abreast of the information on important developments happening in their firm, thereby placing them in a good position to solve budding problems quickly.

The study findings show corporate social responsibility (CSR) has a significant positive but muted influence on technical efficiency under the CRS assumption. This finding supports the view that good corporate citizenship enhances firm performance. CSR aims to hold corporations responsible for their actions and to promote a positive corporate effect on the environment and stakeholders, including consumers, employees, investors, communities, and others. Corporate governance and corporate social responsibility may reinforce each other in the search for a vision of the firm as an institution, which may create value while having regard for the welfare of stakeholders. This is in line with the observations made by Laan et al. (2008).

Audit committee size (ACS) and frequency of audit committee meetings (FACM) show no significant influence on RCB efficiency. This may be due to the lack or absence of standing audit committees in most of the RCBs in Ghana. This result is somewhat contrary to the findings of De Zoort et al. (2002), which suggest that larger audit committees tend to have better resources at their disposal than smaller ones. Klein (2002) and Kyereboah-Coleman (2008), however, revealed that there is a positive relationship between audit committee size and a firm's performance. The independent work of the audit committee has a great influence on the efficiency of the firm.

\section{Conclusion}

Issues regarding corporate governance are a global phenomenon and its crucial role in financial institutions must not be underestimated. Indeed, good corporate governance is a catalyst for ensuring good performance in the banking sector, in which the RCB industry is not exceptional. RCBs in Ghana have recently moved in the direction of adopting corporate 
governance best practices in order to boost efficiency in their operations. This study was undertaken to uncover the extent to which corporate governance affects RCB performance in Ghana. We estimated the level of efficiency of 70 sampled RCBs using the DEA technique under different assumptions. Our findings suggest that most RCBs are technically inefficient and although some RCBs had attained full efficiency at some points in the sample period, the majority of them were unable to operate at an optimal technical efficiency. In the period 20072011, the sampled RCBs generally suffered an efficiency decline within the period of the global financial crisis. In terms of the effect of corporate governance variables, the study recognized that the board size, frequency of board meetings, and CSR are significant predictors of RCB efficiency. The implication is that managers of RCBs must encourage regular board meetings and also increase investment in corporate social responsibility to improve their performance.

\section{References}

Achim, Monica-Violeta; Borlea, S.-N. M. C. (2016). Corporate governance and business performance: Evidence for the Romanian economy. Journal of Business Economics and Management, 17(3):458-474.

Adnan, M. A., Htay, S. N. N., Rashid, H. M. A., and Meera, A. K. M. (2011). A Panel Data Analysis on the Relationship between Corporate Governance and Bank Efficiency. Journal of Accounting, Finance and Economics, 1(1):1-15.

Adusei, M. (2016). Determinants of bank technical efficiency: Evidence from rural and community banks in Ghana. Cogent Business \&3 Management, 3(1).

Ameer, R., Ramli, F., and Zakaria, H. (2010). A new perspective on board composition and firm performance in an emerging market. Corporate Governance: International Journal of Business in Society, 10(5):647-661.

Anderson, C. W. and Campbell, T. L. (2004). Corporate governance of Japanese banks. Journal of Corporate Finance, 10(3):327 - 354.

Andrieş, A. M., Căpraru, B., and Nistor, S. (2018). Corporate governance and efficiency in banking: evidence from emerging economies. Applied Economics, 50(34-35):3812-3832.

Banker, R. D., Charnes, A., and Cooper, W. W. (1984). Some Models for Estimating Technical and Scale Inefficiencies in Data Envelopment Analysis. Management Science, 30(9):1078-1092. 
Beisland, L. A., Mersland, R., and Randøy, T. (2014). The Association between microfinance rating scores and corporate governance: a global survey. International Review of Financial Analysis, 35(C):268-280.

Berger, A. N. and Humphrey, D. B. (1997). Efficiency of financial institutions: International survey and directions for future research. European Journal of Operational Research, $98(2): 175-212$.

Berle, A. and Means, G. (1932). The Modern Corporation and Private Property. New York: Macmillan.

Black, B. S., Love, I., and Rachinsky, A. (2006). Corporate governance indices and firms' market values: Time series evidence from Russia. Emerging Markets Review, 7(4):361 379. Financial market development in the Central and Eastern European countries.

Bokpin, G. A. (2013). Ownership structure, corporate governance and bank efficiency: an empirical analysis of panel data from the banking industry in Ghana. Corporate Governance: The international journal of business in society, 13(3):274-287.

Charnes, A., Cooper, W., and Rhodes, E. (1978). Measuring the efficiency of decision making units. European Journal of Operational Research, 2(6):429 - 444.

Damme, P. V., Wijesiri, M., and Meoli, M. (2016). Governance and Efficiency of Microfinance Institutions: Empirical Evidence from Sri Lanka. South Asia Economic Journal, 17(2):236247.

De Zoort, F. T., Hermanson, D. R., Archambeault, D. S., and Reed, S. A. (2002). Audit Committee Effectiveness: A Synthesis of the Empirical Audit Committee Literature. Journal of Accounting Literature, 21:38-75.

European Central Bank (2004). European Central Bank. Annual Report: 2004. European Central Bank,Frankfurt.

Fidanoski, F., Mateska, V., and Simeonovski, K. (2014). Corporate Governance and Bank Performance: Evidence from Macedonia. Economic Analysis, 47(1-2):76-99.

Hartarska, V. and Mersland, R. (2012). Which Governance Mechanisms Promote Efficiency in Reaching Poor Clients? Evidence from Rated Microfinance Institutions. European Financial Management, 18(2):218-239.

Huang, C.-J. (2010). Board, ownership and performance of banks with a dual board system: Evidence from Taiwan. Journal of Management and Organization, 16(2):219 - 234. 
Jensen, M. (1993). The Modern Industrial Revolution, Exit, and the Failure of Internal Control Systems. Journal of Finance, 48(3):831-80.

Jensen, M. C. and Meckling, W. H. (1976). Theory of the firm: Managerial behavior, agency costs and ownership structure. Journal of Financial Economics, 3(4):305 - 360.

Klein, A. (2002). Audit committee, board of director characteristics, and earnings management. Journal of Accounting and Economics, 33(3):375 - 400.

Kyereboah-Coleman, A. (2008). Corporate governance and firm performance in Africa : a dynamic panel data analysis. Studies in Economics and Econometrics, 32(2):1-24.

Laan, G., Ees, H., and Witteloostuijn, A. (2008). Corporate Social and Financial Performance: An Extended Stakeholder Theory, and Empirical Test with Accounting Measures. Journal of Business Ethics, 79(3):299-310.

Laeven, L. and Levine, R. (2009). Bank governance, regulation and risk taking. Journal of Financial Economics, 93(2):259 - 275.

Murillo-Zamorano, L. R. (2004). Economic Efficiency and Frontier Techniques. Journal of Economic Surveys, 18(1):33-77.

Ntim, C. and Osei, K. (2011). The impact of corporate board meetings on corporate performance in South Africa. African Review of Economics and Finance, 2(2):83-103.

Oteng-Abayie, E. F. (2017). Technical efficiency and total factor productivity of rural banks in Ghana. Cogent Economics \&3 Finance, 5(1):1366088.

Paxton, J. (2003). A poverty outreach index and its application to microfinance. Economics Bulletin, 9(2):1-10.

Poudel, Ravi Prakash; Hovey, M. (2013). Corporate governance and efficiency in Nepalese commercial banks. International Review of Business Research Papers, pages 53-64.

Rao, K. and Desta, K. (2016). Corporate Governance and Financial Performance: A study with reference to Commercial Banks in Ethiopia. International Journal of Applied Research, 2(8):551-557.

Romano, G., Ferretti, P., and Rigolini, A. (2012). Corporate Governance and Performance in Italian Banking Groups. In "Corporate governance $\mathcal{E}$ regulation: outlining new horizons for theory and practice". 
Salim, R., Arjomandi, A., and Seufert, J. H. (2016). Does corporate governance affect Australian banks' performance? Journal of International Financial Markets, Institutions and Money, 43:113 - 125 .

Soba, M., Erem, I., and Ceylan, F. (2016). The impact of corporate governance practices on bank efficiency: A case of Turkey. Journal of Suleyman Demirel University Institute of Social Sciences, 25(3):305-322.

Tahir, M. W. C. W. A. (2015). Effects of Corporate Governance on Organization Performance: Evidence from Banking Sector of Pakistan. Journal of Business and Management, $17(3): 75-82$.

Tai, L. (2015). The Impact of Corporate Governance on the Efficiency and Financial Performance of GCC National Banks. Middle East Journal of Business, 10(1):12-16.

Tanna, S., Pasiouras, F., and Nnadi, M. (2011). The Effect of Board Size and Composition on the Efficiency of UK Banks. International Journal of the Economics of Business, 18(3):441462.

Thanassoulis, E., Boussofiane, A., and Dyson, R. (1996). A comparison of data envelopment analysis and ratio analysis as tools for performance assessment. Omega, 24(3):229 - 244 . 
Figure 1: Average Technical Efficiency: VRS Output Oriented (2007-2013)

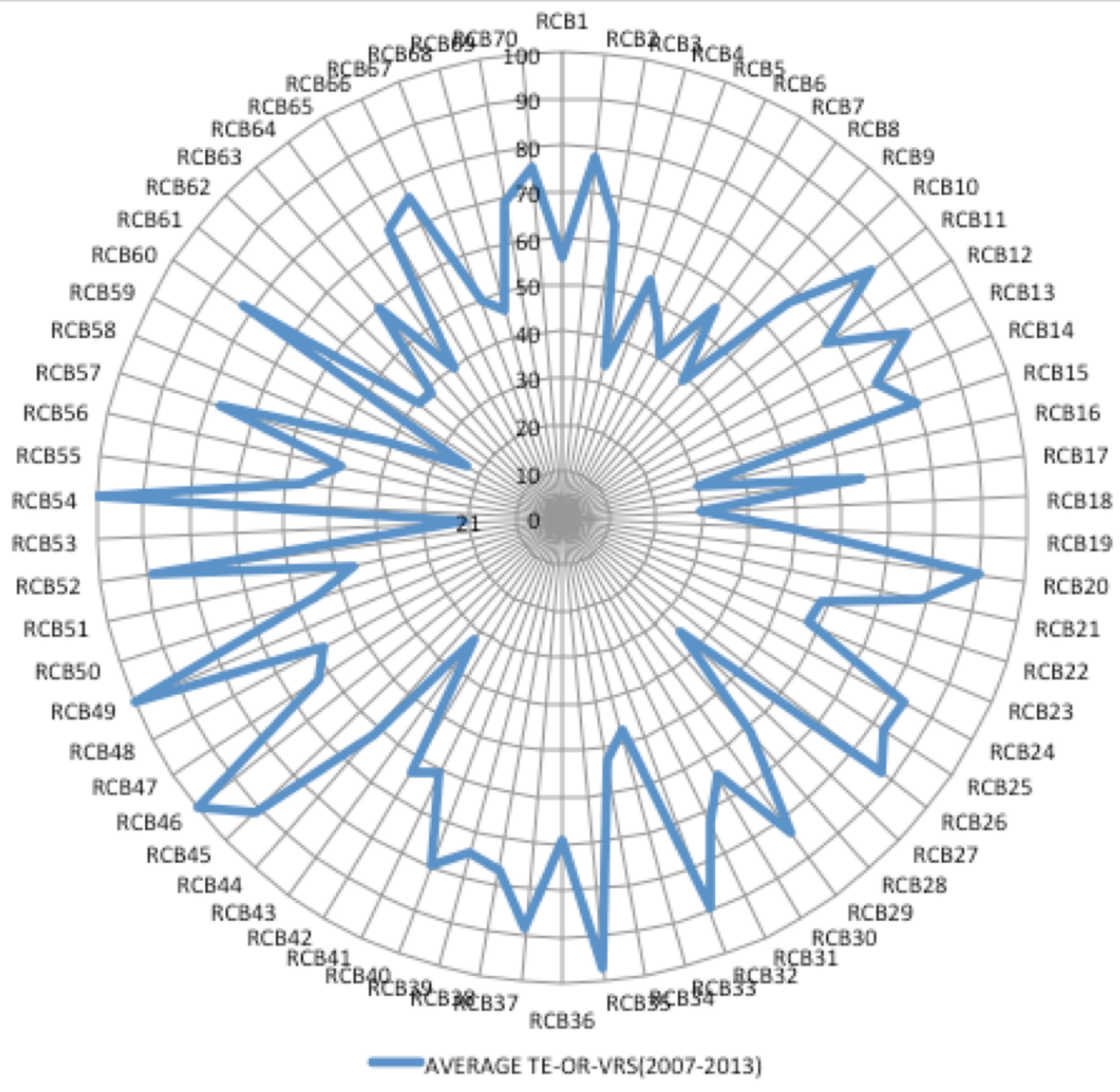


Figure 2: Average Technical Efficiency: VRS Input Oriented (2007-2013)

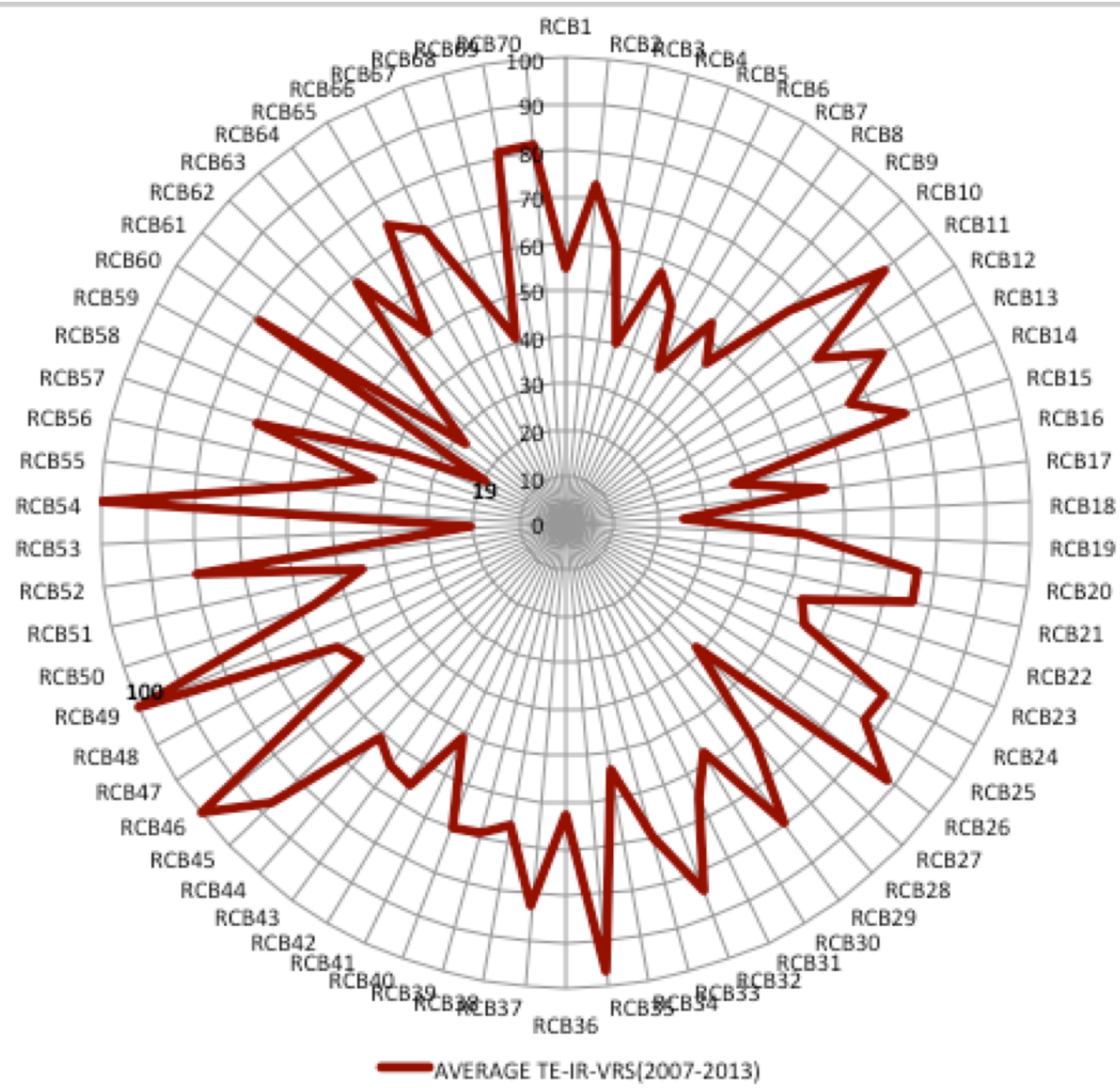


Figure 3: Average Technical Efficiency: CRS (2007-2013)

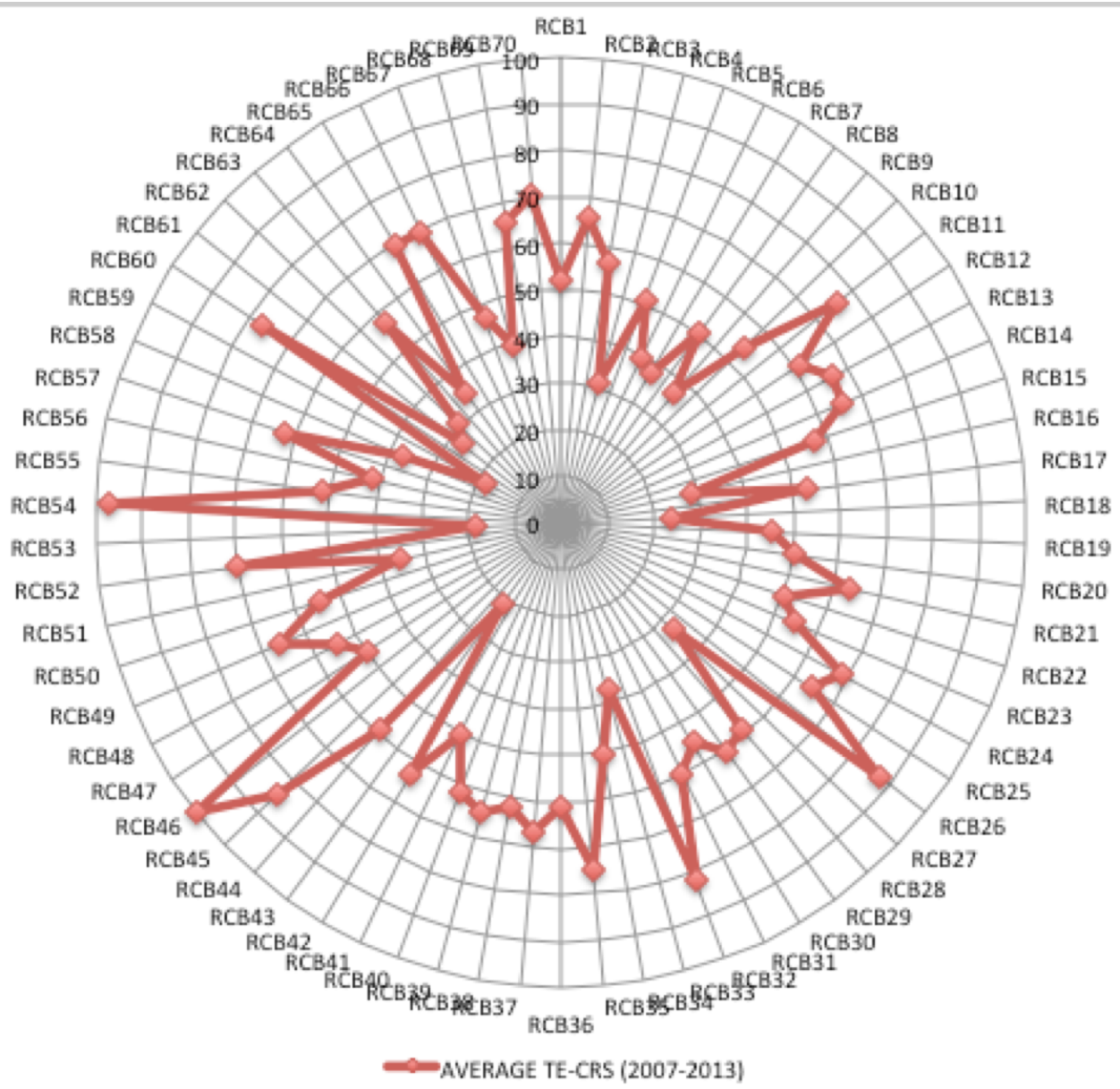


Figure 4: Trends in Overall Average Technical Efficiency (2007-2013)

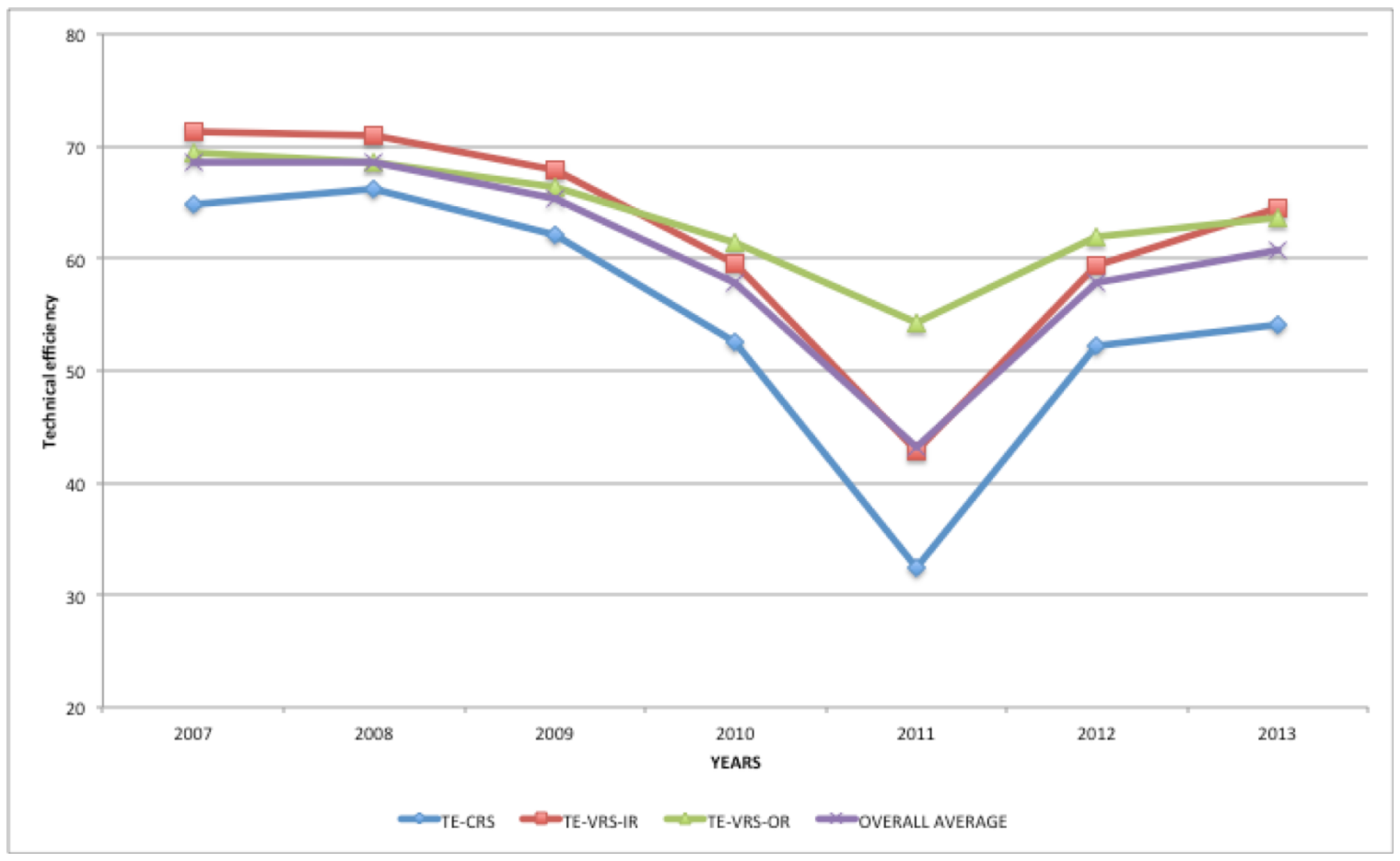




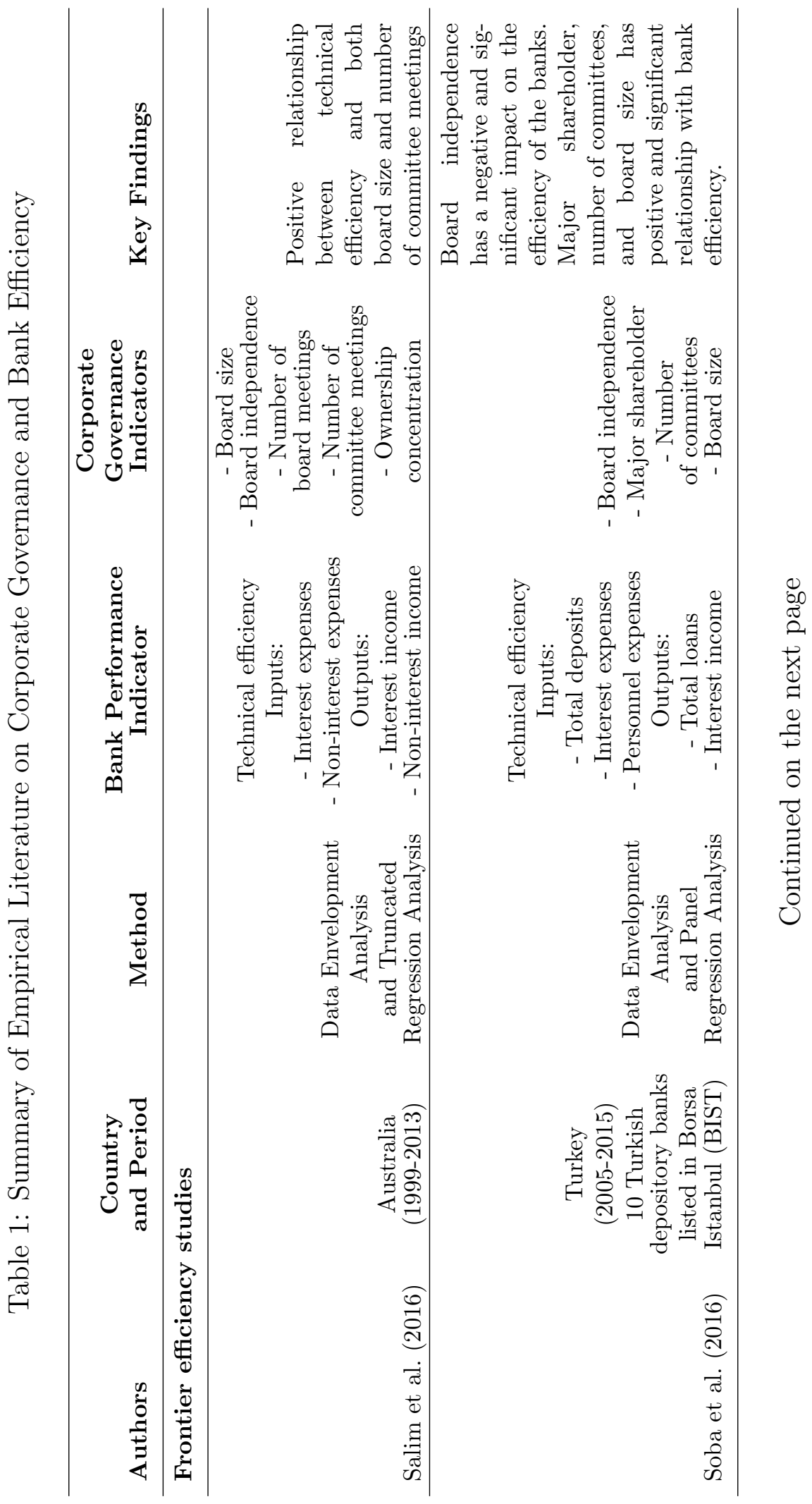




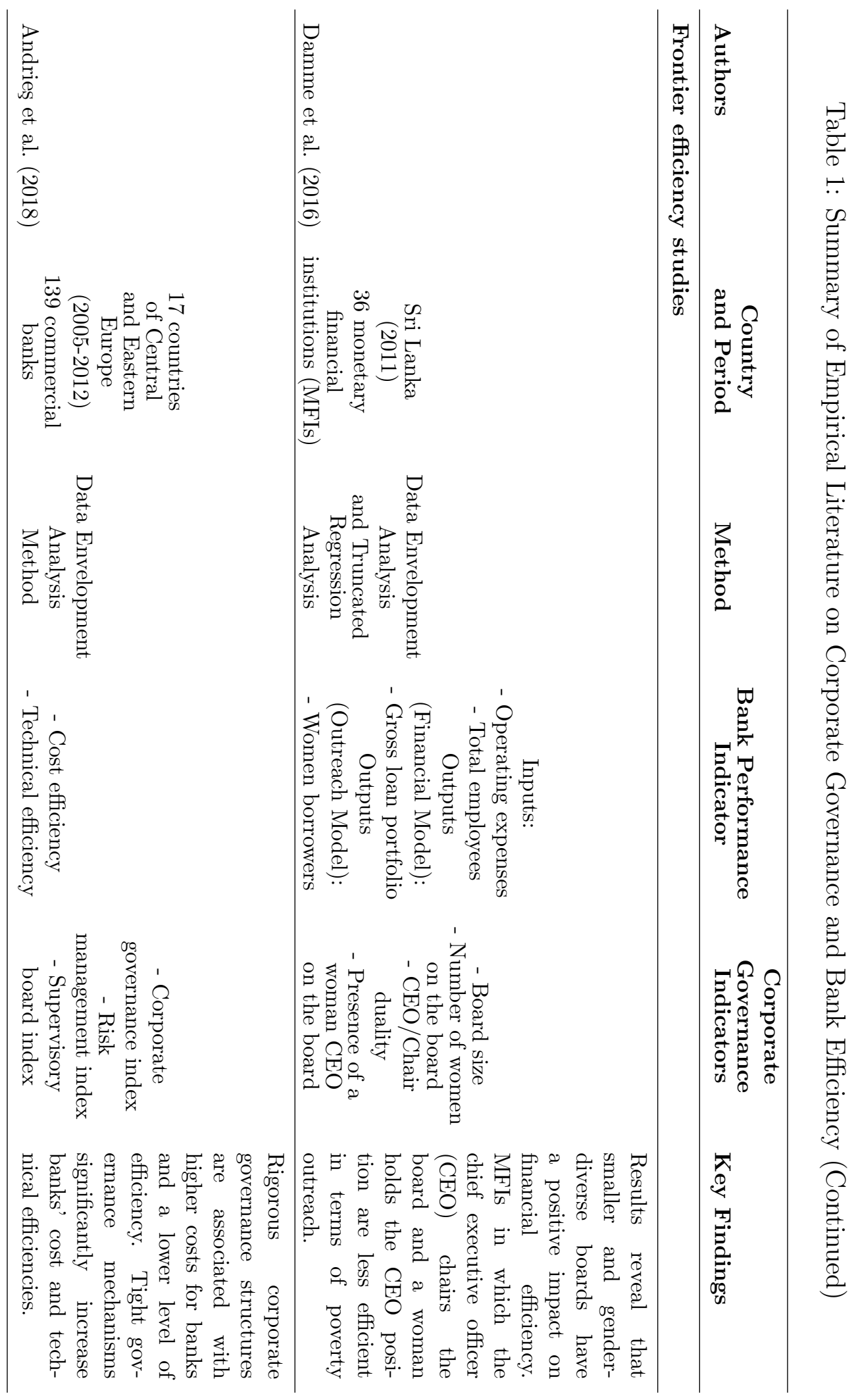




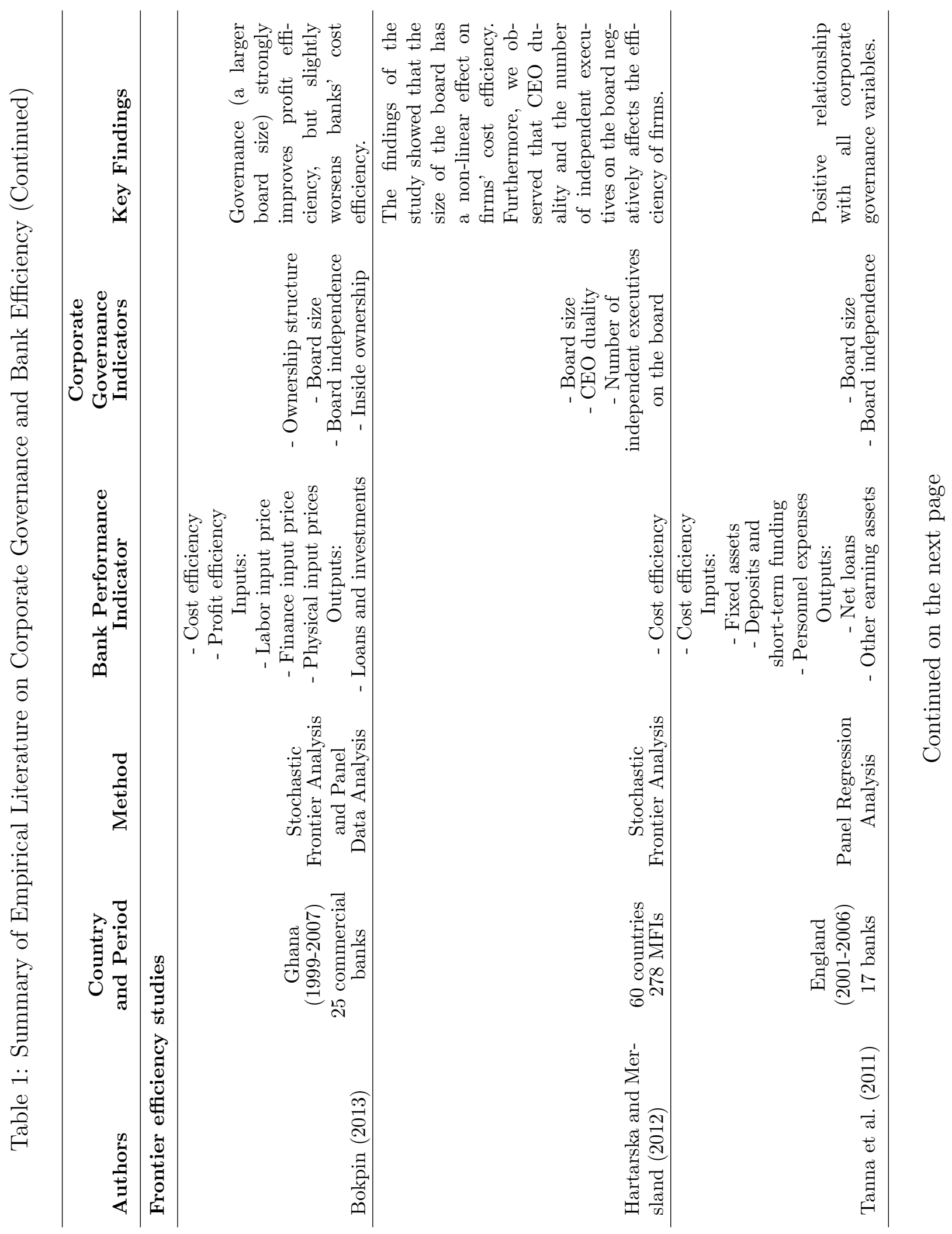




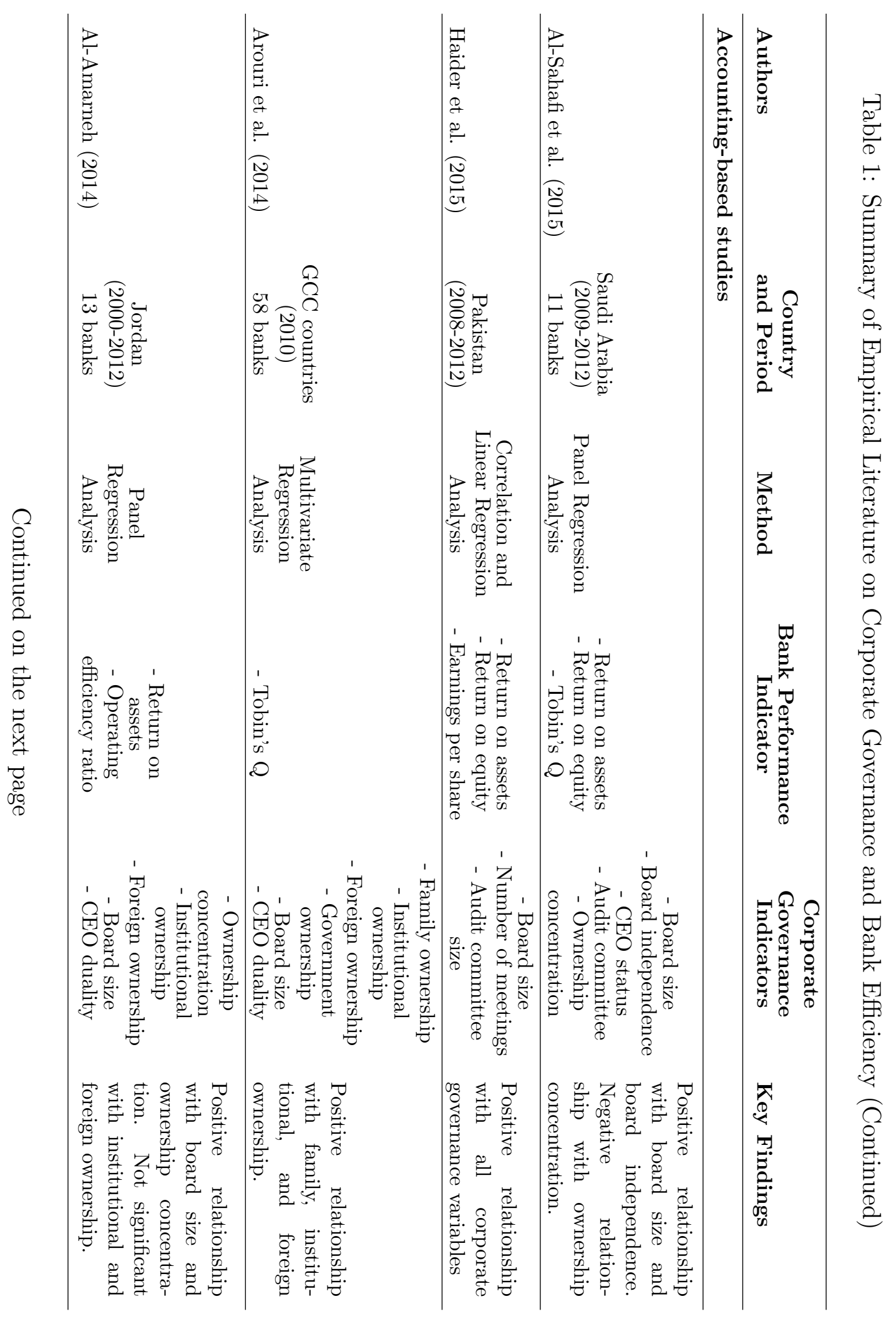




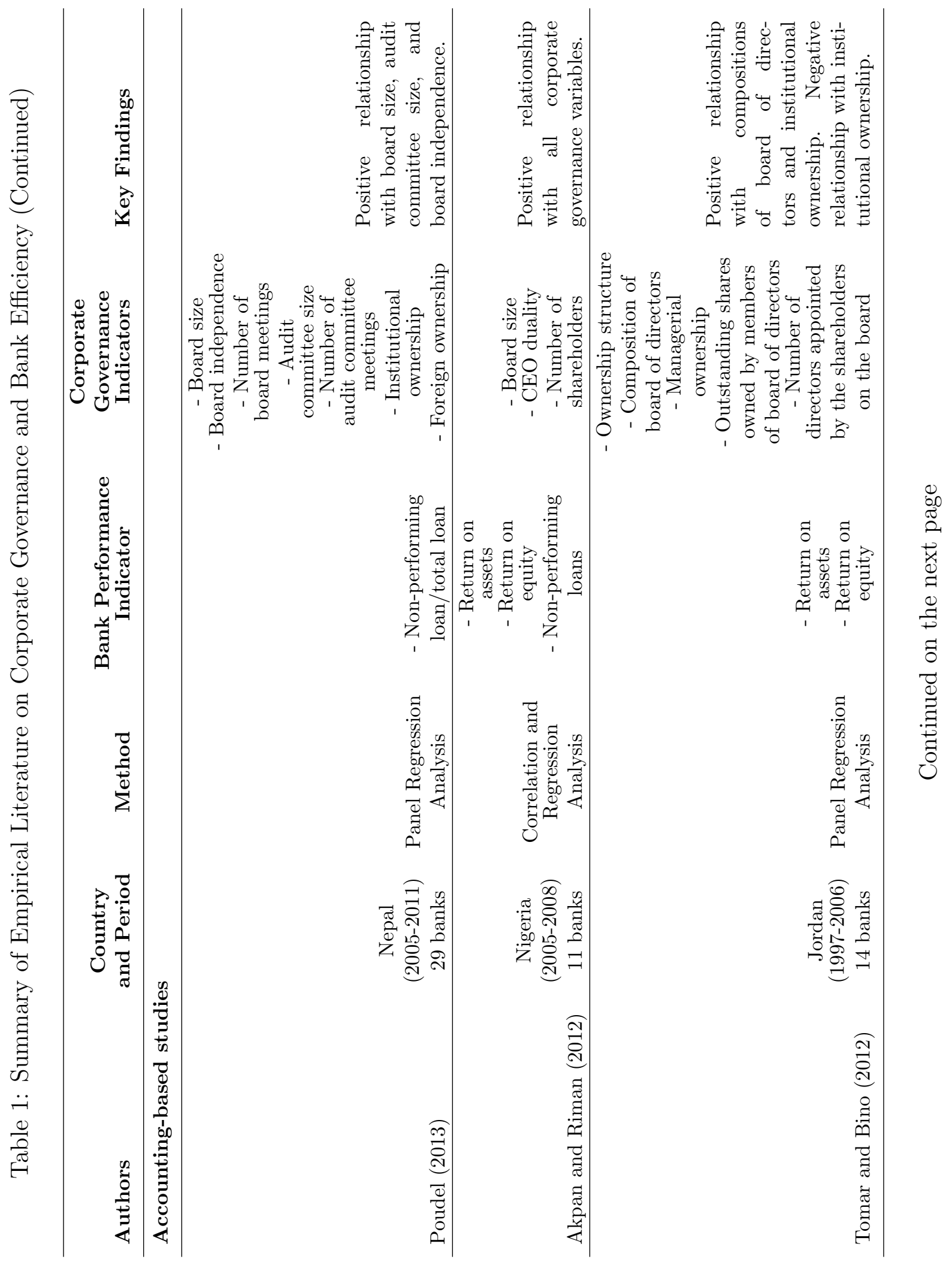




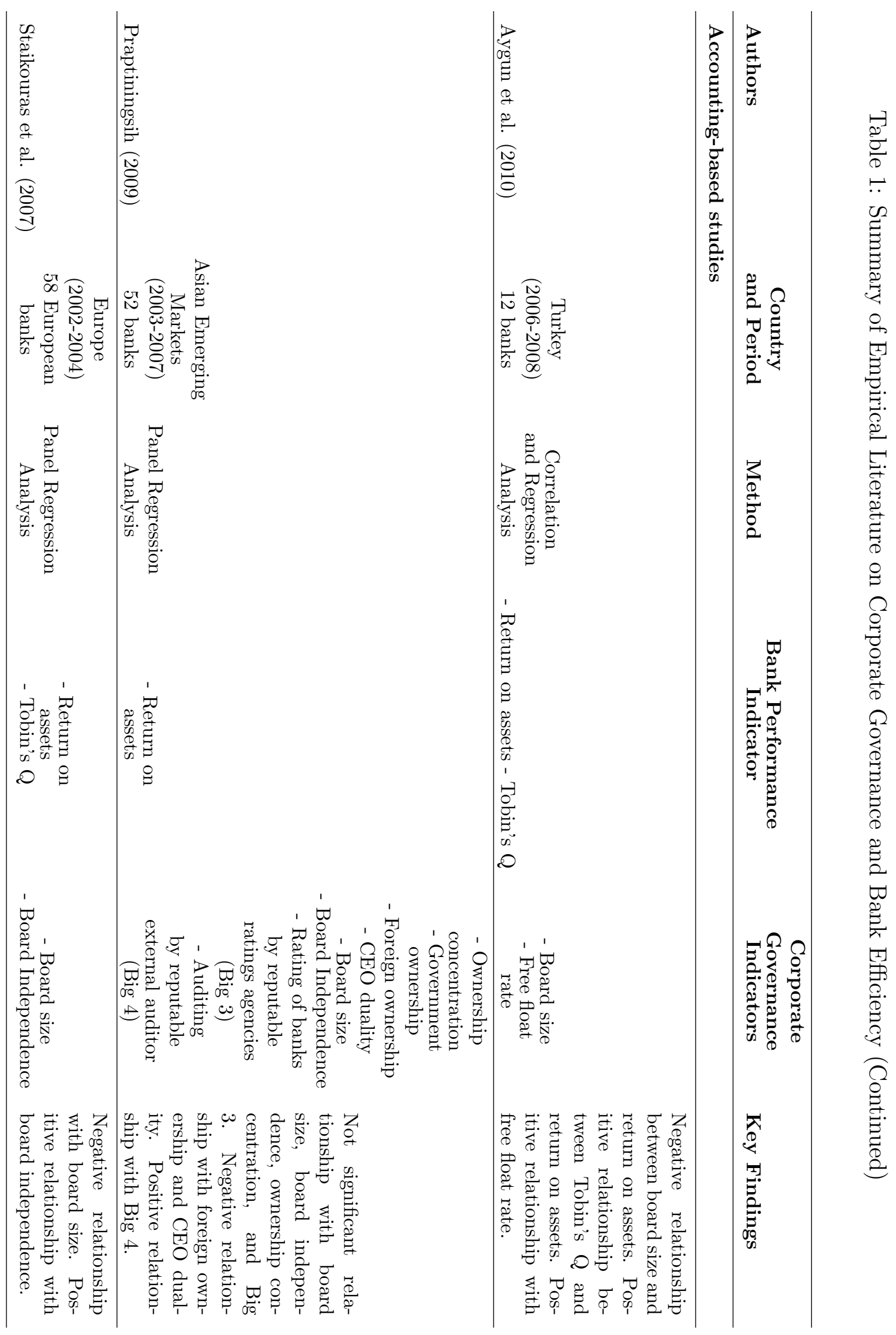




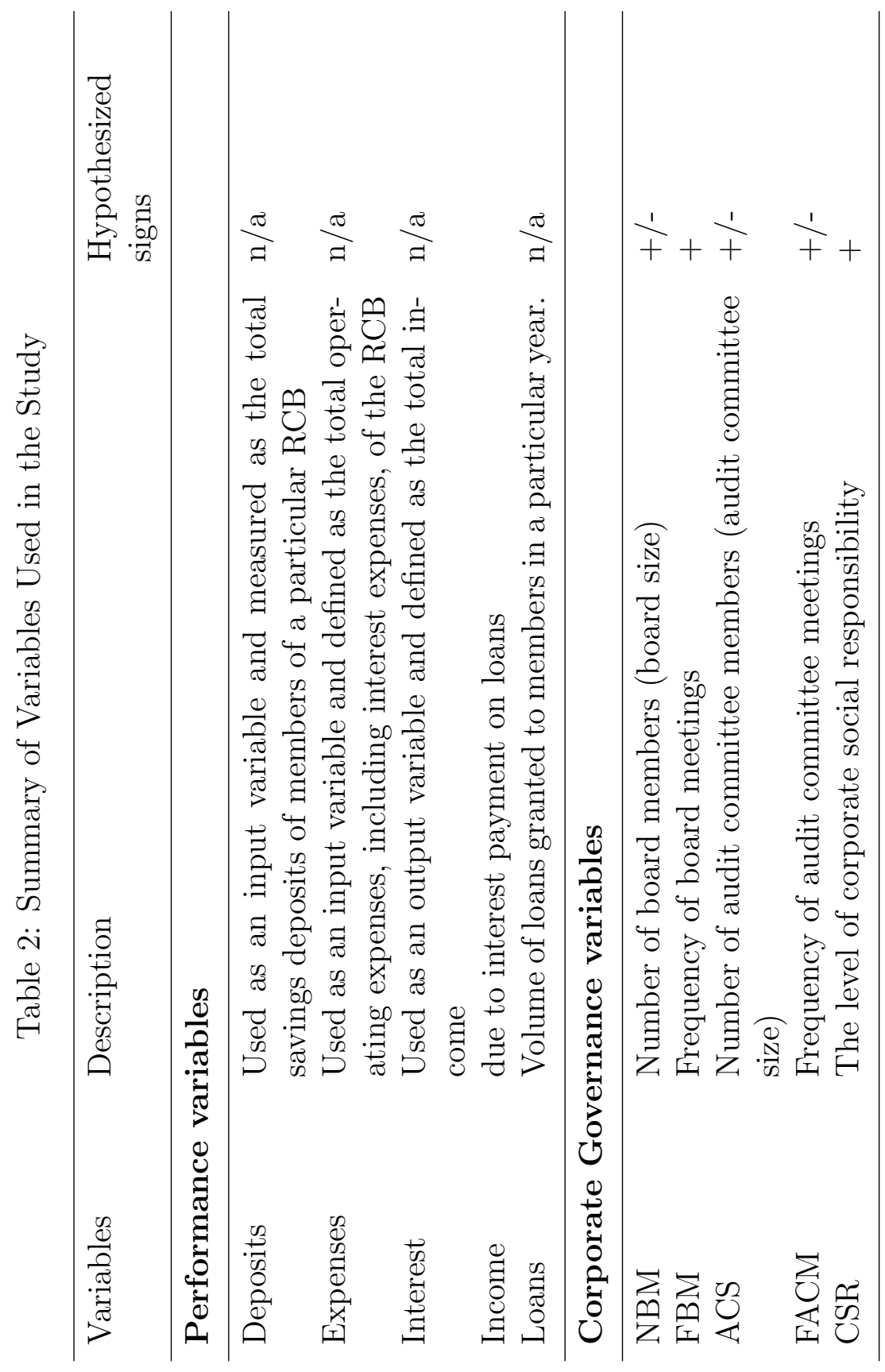




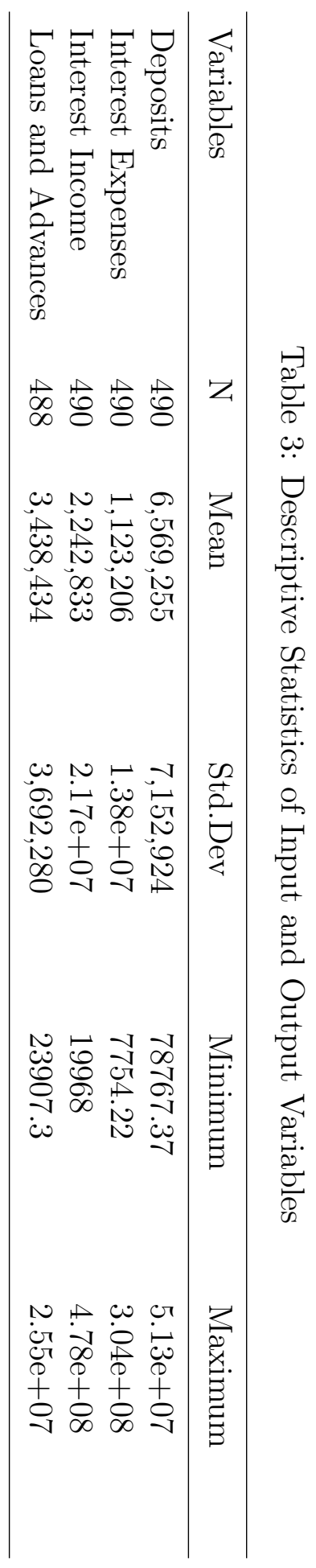




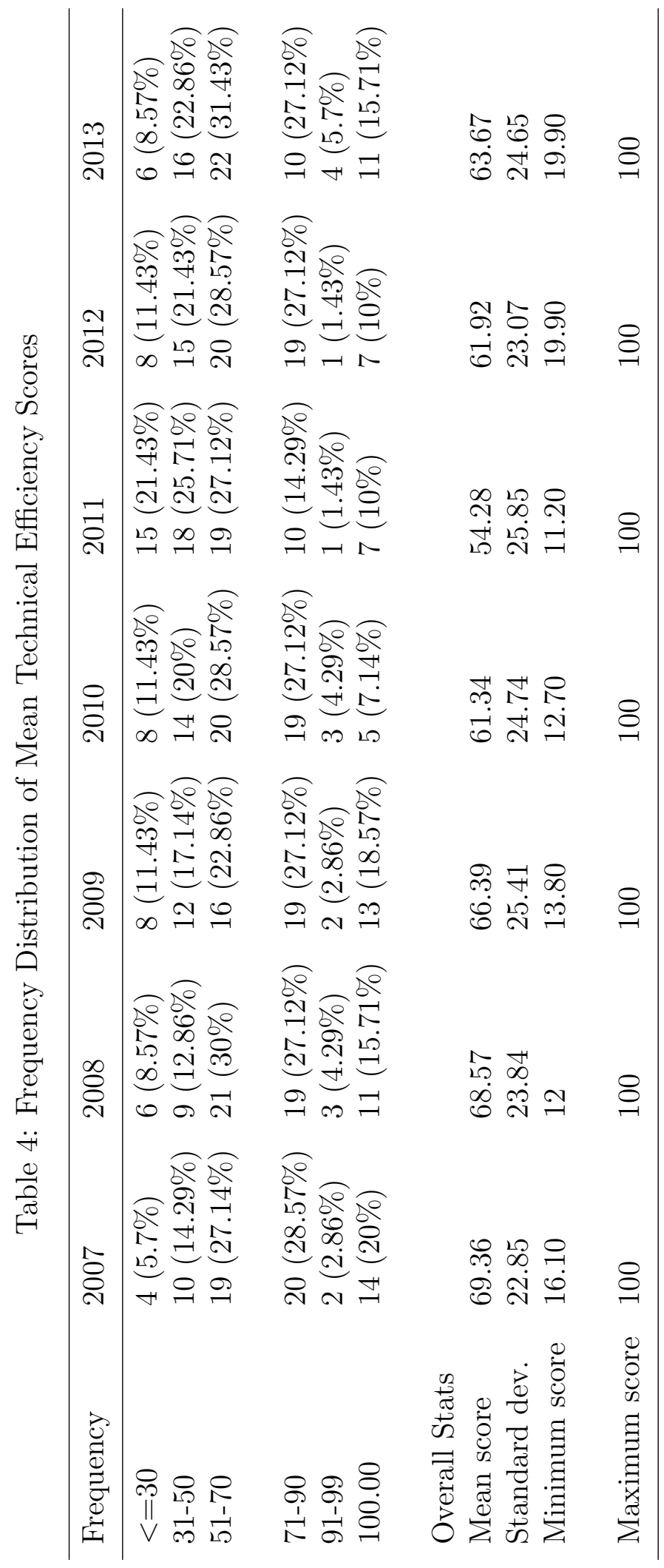


Table 5: Effect of Corporate Governance on RCB Technical Efficiency (TE)

\begin{tabular}{lccc}
\hline \multicolumn{4}{c}{ Efficiency Models } \\
Variables & TE (OR-VRS) & TE (IR-VRS) & TE (CRS) \\
\hline Constant & $46.80^{* * *}$ & $46.42^{* * *}$ & 22.63 \\
& $(15.22)$ & $(15.86)$ & $(14.30)$ \\
NBM & $4.613^{* *}$ & $3.888^{*}$ & $6.008^{* * *}$ \\
& $(1.950)$ & $(1.977)$ & $(1.829)$ \\
FBM & 0.685 & 0.433 & $1.212^{*}$ \\
& $(0.708)$ & $(0.720)$ & $(0.669)$ \\
FACM & -2.079 & -0.905 & -2.671 \\
& $(2.557)$ & $(2.613)$ & $(2.399)$ \\
ACS & 0.157 & 0.123 & 0.179 \\
& $(0.559)$ & $(0.571)$ & $(0.55)$ \\
CSR & 0.00009 & 0.0003 & $0.0004^{* *}$ \\
& $(0.0002)$ & $(0.0002)$ & $(0.0002)$ \\
\hline F(5,64) & 1.44 & 1.31 & $3.88^{* * *}$ \\
R-squared & 0.1013 & 0.0929 & 0.2325 \\
Root MSE & 18.892 & 19.218 & 17.793 \\
\hline
\end{tabular}

